\title{
Cyprus: Solution as Liberalization
}

\author{
By Lambros Philippou*
}

The Cyprus issue, as it has been conceptualized for over a century and as it has materialized itself through specific historical events, could be identified with the will of the prolonged and troublesome movement of the Cypriot consciousness to achieve for itself a higher stage of development, and by virtue of this, to subject actual reality to a process of gradual improvement. From this suggested point of view, the problem needs to be addressed in terms of the stage of the growth of consciousness in different historical periods and its drive to construct a functional mode of rationalism. That is to say, to readjust and enlarge the parameters of survival on the Cyprus land and render them compatible with its interactive environment. More specifically, the prospect of solution should be understood as an evolutionary process of development of Cyprus consciousness through which systems of thought and the network of practices, institutions and the prevailing Cypriot reality will be liberalized as a whole. Thus solution equates with the Cypriot consciousness entering into a stage of development whereby it can autonomously attain an authentic will for liberalizing the reified world upon which it has built and has been constructed. This, in its turn, will result in a rational and an evolutionary resolve for communication with both the other Cypriot world and other international systems of reason. This very fact amounts to an entering into a new evolutionary phase in which the process of liberalization of Cyprus as a whole will be accelerated.

Keywords: closure, functionality, nomadic rationalism, liberalization, rhythmoanalysis, temporality,

\section{Introduction}

Hegel, and following him, Kojeve and Fukuyama, placed great importance on the issue of the existential desire for recognition that is perceived as the motor of historical process. This is considered as the hidden force which animates the impulse to negate reality in order to conform it to that which is not yet reality and which underlies any civil or external war (Hegel 1956, Fukuyama 1993). ${ }^{1}$ From this perspective, the modern liberal state, by means of rendering itself contradiction-free, is judged to be satisfying the desire for recognition and preventing the eruption of war. In the present analysis, the desire for recognition is replaced by the evolutionary insertion of a world sphere, through multiple originated mechanisms of reflection, with a sphere of beliefs and a network of practices that serve enlarged islands of functionality. The actualization of existential conditions on the basis of shared islands of communicability, allows the smooth passing from one world to another. This is indeed connected with a certain

\footnotetext{
${ }^{*}$ Assistant Professor, American College, Cyprus.

${ }^{1}$ Kojeve (1980: 41) codifies this position as follows: "human, historical, self conscious existence is possible where there are, or -at least- where there have been, bloody fights, wars for prestige".
} 
stage of development of consciousness which is animated by a reflective attitude towards inherited reality, as has been actualized in western liberal democracies. The results of the absence of this evolutionary stage of consciousness are obvious in microwords that have not yet fully developed powerful mechanisms of social and political functionality. In real terms, what is lacking in these worlds "in closure" $^{2}$ is a solid network of workable beliefs and the reified environment in which they are generated and perpetually recreate. This universe of beliefs prevents a world from collectively enclosing itself within a horizon without an outside. For, they are spirited by an ethical quality that can create a field for communicative action which weakens the ontological barriers in favour of a universal human condition. ${ }^{3}$ The novel planetary human condition, heralded by the informational revolution of the 1990s' brings with it the impossibility of a world to be closed within itself (Tarrow 1998). That is to independently raise singular claims of validity as far as the measuring of functionality and applicability is concerned. The new world therefore emerged by way of a process of widening the parameters of survival, out of which the uninhabited zones that create the possibility of war are gradually being transcended.

Unlike the theorists of "the end of history", it is here argued that what has been called a liberal state could be identified with the materialization of the long process of the movement of enlightenment that has governed western reason since the beginning of the $17^{\text {th }}$ century. This movement aims at establishing an active field in which the correspondence between discoursive claims and the constant flow of the external reality is subjected to a permanent test of adjustment, governed tenacity for truth, authenticity and sincerity (Arendt 1978, Trilling 1971, Foucault 2001). ${ }^{4}$ This differentiation leads to various conclusions as far as the claim for "the end of history" and the understanding of the reality of the liberal state in its social and economic settings are concerned. From the perspective of this analysis, the liberal state is assumed as a state of collective being in structural openness, which, via a culture that accelerates reflective attitudes, constructs well founded islands of functionality and corrects distortions in a timely fashion without allowing them to accumulate. Moreover, the liberal state permits both the existential relationship with it in addition to guarding for itself the possibility of

\footnotetext{
${ }^{2}$ According to Castoriadis (1997a: 17), this term refers to the absence of openness understood as a process of radical questioning of the given: "the state where laws, principles, norms, values, and meanings are given once and for all and where the society or the individual, as the case maybe, has no action upon them". Castoriadis (1997b: 17) attributes to these societies the ahistorical: they "think of succession only from the point of view of identity. Causality, finality and implication are merely amplified and unfolded forms of an enriched identity".

${ }^{3}$ E. Banfield's (1958) account of Liverno could be served as the ground for reflecting on the environmental and cognitive structures that sustain such a world, while at the same time they threaten its workability. However, the structural forces behind a culture of violence cannot be identified with the rural society. Rather, they are related with weak mechanisms of reflection that produce conscience, that is, models of functionality. In their extreme form, such mechanisms can be found in a rural society but they exist elsewhere in a modified form, yet portraying the same structural properties.

${ }^{4}$ These core values inform models of long run functionality that serve a population that is subject to a continuous process of expansion. Thompson (2002), from the point of view of evolutionary biology calls them "fitness-enhancing concepts", hence their viability and sustainability.
} 
being subjected to corrective divergence and modification. ${ }^{5}$ This refers to a world that aims at reconciling the never ending gap between discourses and visible reality, by establishing mechanisms which develop a mode of personal, social and political government based on a core of ethical values. As a structural consequence of this, it traces and eliminates symptoms of corruption, mistrust and hypocrisy. Because of this inherent will for authenticity -understood as a systemic will to correct any discrepancies between reason and reality and its compulsive intolerance to leave a distorted regime of truth unfolding uninterrupted -a structural rhythm has been established which lies entrenched in the roots of the western liberal state. The main property of this rhythm consists of managing the circulation of ontological and institutional constructions by measuring what is functional in the long run. The structural strength of a functional world is based on the fact that whatever can take ontological content addresses only a fundamental existential human condition and a state of mind. ${ }^{6}$ The interplay between the subjective and the objective structure of the world leads to a constant actualization, enrichment and readjustment of both. Hence, the very condition for the existence of an open and functional world is the recurring and diversely originated existential connection with its ontological structure. So, to render a state of things liberal is to establish a permanent field that is governed by a mode of being whereby the mechanisms of enlightenment generate a more enlarged, functional and adjustable mode of consciousness. Similarly, what distinguishes Western democracies from closed worlds is this core of mechanisms deeply embedded in the social, political, educational and economic life worlds that at a fast pace construct, promote and perfect systems of workability that are being tested both inside and outside of the microcosm itself.

\section{The Rhythmnoanalysis of the Cypriot Environment}

Throughout history, the Cyprus environment has facilitated a flow of movement that generates and thereafter retains unexamined a set of collective representations that function without an outside challenge. ${ }^{7}$ Slow rhythm is the condition of the existence of societies in closure because the slow flux of events enables the objectification on the basis of their own ready-made tools of perception without allowing the events themselves to invent in their established

\footnotetext{
${ }^{5}$ For the combined energy of the properties of structural modifiability and of a developed sense of justice conveyed by institutions, see Toqueville (1969) and Rawls (1971) respectively.

${ }^{6}$ Lefebvre (2004) points to a direction where the reified common world is subjected to the mutation of mental and spatial places that condense claims of functionality. The suppression of such subjective claims may even lead to revolutionary acts.

${ }^{7}$ Cypriot closure subjugates whatever falls inside its sphere of influence. Under its all-encompassing energy, mutability is replaced with atemporality, and as a result, the modernization process is put on hold. On the conceptualization of this Cypriot environmental reflective defect, see Georghallides 1985, Luke 1957, Adams 1971: 93-94. Packard (2008: 52) refers to a society which has developed itself in a "sealed environment". Lanitis (1963: 19) connects closure with a limited horizon of ethical responsiveness, what he calls, "the lack of a frame of mind": among other things, "the ability to think and take action on the basis of certain well defined moral standards that enable men to tell between immediate short lived benefits and latent long-term values".
} 
mechanisms of reception a novel space where they can be creatively accommodated. The movement of Cyprus history is governed by an extremely closed and highly cultivated temporality consisting of mechanisms of observing, interpreting and filtrating what enters its world. Therefore the mechanisms of producing islands of functional rationality and those of correcting distortions have been inadequate, in terms of both the internal and the external wave of challenges for adjustment: hence the reduced ability of the Cypriot consciousness for mutability within the historical process. As a byproduct of this, the history of Cyprus denotes a chain of crises, being defined as the moments of the sharp illustration of a disorientated consciousness that struggles to materialize its authentic will to live in a more advanced state of things, but failing to do this successfully.

Due to this historically demonstrated unworkability, Cypriot hegemonic ideology condenses the moments of failure into the core of its ideology as masked and unexamined "values", instead of reopening itself. According to Castodiadis (1997a, 1997b) the creation of the world itself exists always in closure, defined by specific conceptual boundaries and categories. The fact that we always live within closure means that the way we see the world is always conditioned. The movement from the outside environment to the inside of the cognitive structure is conditioned by the internal laws of the structure itself. However, societies manifesting strict closure subject history to stability and repetition. In this case, such societies are more inclined to preserve what exists and are less disposed to transform it through its negation. As a result, the way Cypriot society represents and institutes itself makes the process of its self-alteration too slow for the products of the instituting activity to regain mastery over the reflective activity itself. In effect it is a reversal whereby an institution develops its own internal logic, and whatever falls outside of it, is exposed to its own function.

Historicity does not mean preserving the existing order of things, but transforming and recreating it. The latter, represents culturally and institutionally the preservation of the new stage of development that consciousness has achieved. ${ }^{8}$ Therefore, to follow the movement of the Cypriot spirit towards its selfdevelopment is to follow the points of rupture within Cypriot closure. These points take the form of a multi-layered accumulation of islands of functionality that branch off from the objective reality. Throughout a reflective attitude on the Cyprus microcosm and despite the bitter flavor that Cyprus history leaves, there is a silent history, yet at work: that of a slow but gradual development of nomadic rationalism. This alludes to a network of revolutionary islands of thought, deeply rooted in the Cypriot spatiotemporal environment. As such, these islands are compulsively oriented towards deconstructing the reified world which the destructive Cyprus closures bequeathed to Cypriots. The inherited world,

\footnotetext{
${ }^{8}$ As Hegel (1956: 54) remarks, it is "a real capacity for change, and that for the better -an impulse of perfectibility". Kojeve (1980: 209) puts it as follows: "creative evolution, that is, the materialization of a future that is not a simple prolongation of the past through the present, is called History: = Negativity = Action = History". Castoriadis (1997b: 193) addresses the same issue as follows: "time can exist only if there is an emergence of what is other, of what is in no way given with what is, what does not go together with it. Time is the emergence of other figures".
} 
perceived as the illustration of closures' limitations and employability is a remnant of the finished trajectory of their materialization in the historical process.

\section{The Traces of Nomadic Rationalism in Cyprus History}

In the course of Cyprus history, in a being-alongside mode, there is a parallel development of what this author will call "nomadic rationalism." The term nomadic rationalism, refers to the imaginary corrective attitude towards strict closures. A distorted world -being structural and layered as such- matures by reaching its aporetic dialectic. Thereafter, it calls for the overcoming of its accumulating contradictions. Despite that, Cypriot closures perceive a crisis as a moment that enables them to rearrange and reaffirm themselves. In reality though, the moment of crisis, by releasing ontological tools to nomadic rationalism, weakens closures. In fact, the force of the constant flow of outside reality reveals their disassociation from it in terms of correspondence and functionality. Nevertheless, because this precise fact is not materialized in thought immediately, it allows them to continue using impractical tools. In this way, the historical experience of Cyprus accumulates a stock of failure of thought on which nomadic rationalisms reflect.

When a break in Cypriot cognitive and representational closure occurs, the ensuing ontological content is accommodated by nomadic rationalisms that gradually function as an internal force of corrective impulsion. In this sense, the antagonistic struggle between closures and nomadic rationalisms refers to a struggle between historicity and mechanical self-made temporality. That is, on the one hand between a will to make itself an objective reality and breathe in historicity, and on the other hand, a compulsion to withdraw in atemporality through a drive to retain whatever became a reified objectification. Nomadic rationalisms emerge out of the chains of crises. When the closed worlds respond to the external flow of events by recognizing, categorizing and ordering them on the basis of their own ossified structures, there is always a remaining of meaning. This residue exists because of the invisible islands of freedom through which every response to events results in a slight break within the established mechanisms of reception. This means that the hegemony of closures on time and space has ruptures for the very reason that when something appears and is expelled it does not disappear. The history of Cyprus is contaminated with such fragmented blocks of truth that are waiting for recognition and synthetic reactivation. Even though the mechanisms of closures pursue their lonely march in history by an act of withdrawal, the events pioneer a space within them in which they are trying to fit themselves. It is within the field of these invisible islands of freedom that nomadic rationalisms -as corrective responses to the failures of closures- retain ontological content and enter the field of historicity. 


\section{The Actual Manifestation of Nomadic Rationalisms within Cypriot History}

As monitored by a certain type of British consciousness, there was within the modern colonial environment an objectified splitting of the spatiotemporal field. It is within this field that the Cypriots began the modern phase of reification of their consciousness. A large part of the Cypriot system of reification was controlled by the British colonial consciousness and the Cypriots were divided as far as the systemic mechanisms of its reception were concerned. ${ }^{9}$ Though this split, from a cosmopolitan point of view, made ethnic conflict thinkable in the short-term, it marked the shadowy beginning of a progressive movement of Cypriot consciousness.

Greek Cypriots articulated a compulsive will for a progressive leap to another ready-made reality through the ideology of "enosis" with Greece. Enosis was the temporary ontological arrest of an authentic will of the Greek Cypriot consciousness -resulting from the realization of its early stage of development- to throw itself into a radical process of self-alteration. ${ }^{10}$ Nonetheless, in the Cypriot microcosm the mechanisms of instituting activity that ground the ability of thought to retain a relation of autonomy with its own products were structurally weak. Thereafter, these mechanisms sunk this ideology into a frozen obsession which progresses autonomously throughout history, resisting any reflective reopening and crystallization of its real dialectic whatsoever. The evolutionary figuration of the future that found a refuge in the ideal of enosis, and therefore, the will for transforming reality, from a point onwards, it works as the protective mechanism for the endurance of the past. Additionally, this ossified ideology transmits a mode of reaction to the splitting in half of the Cyprus consciousness the - Turkish Cypriot one.

The Turkish Cypriot consciousness raises the axiom of "taksim", that of territorial, constitutional, social, economic and existential division. In real terms, the ideology of taksim condenses the ontological maturation of the Turkish Cypriot mistrust for the Greek Cypriot ability to institute and manage a viable, inclusive and a just world (McHenry 1987: 28-31, 151-152, Reddaway 1986: 13, 22): ${ }^{11}$ hence the regressive attachment of the Turkish Cypriot consciousness to the institutional and political apparatus of the British colonial power. Moreover, such a partitionist ideology displays the realization of its own late stage of development in relation with the Greek Cypriot spirit whose mode of energetic culture is conceived as a threat for dominating the Cypriot environment. There is actually an

\footnotetext{
${ }^{9}$ See the spirit of Storrs' (1945) analysis. In fact, there is a quasi-liberal guarantee of the Cypriot environment that was both the condition of the existence of the movement of enosis and the force of the internal reconstruction of the colonial power. This quasi-liberal shield conditions the speedy movement of Cyprus history and institutes beyond the power of the Cypriot closures.

${ }^{10}$ For the initial and authentic will for liberalization that the ideal of enosis expressed along with its various ontological contents until its ontological stagnation, see Loizos 1974, Kyrris 1996: 336, Georghallides 1979.

${ }^{11}$ The Turkish Cypriots did not trust the liberal qualities of the Greek Cypriot consciousness. The withdrawal of the liberal guarantee of the Cypriot environment by the British meant for them their own elimination. After 1963, this mistrust towards the Greek Cypriot moral and mental system became a structural element of the ideology of division. See Packard (2008).
} 
initial qualitative differentiation between the ideologies of enosis and taksim. While the first refers to an attempt to expand an ideological grounding of an unreflected evolutionary process of development, the second refers to the spatiotemporal imprisoning of historical process. However, since the structural laws for the unfolding of both ethnic ideologies were set up by the rapid process of liberalization of Cypriot land initiated by the colonial British spirit, these ideological constructs did not control the conditions of their existence themselves. Thus they could not be aware of their real historical dialectic, which although split, worked in the long term as posturing the possibility of correcting one another and of merging together.

What characterizes these two rigid ideological spheres that dominated the two ethnic worlds is the closeness of their horizons, their structural aggression and their instrumentality. These regimes of truth with strict limits of employability, deeply rooted in the Cypriot spatiotemporal environment appear very clearly in the years following the 1960 constitution. Before 1960, the synthetic ability of British reason, due to its positive asynchronization with the two ethnic consciousnesses, understands the destructive dialectic of both, and therefore, from a point onwards, wants to institute on the basis of an inclusive model of survivability. ${ }^{12}$ After 1960 , the British instituting intervention withdraws and is replaced by a codified corrective mechanism which appears from the outside, in the form of the Cypriot constitution. The constitution could not have been conceptualized by the split Cypriot consciousness because the latter had not any evolutionary affinity with its origins; its articulation could have only come from outside (Attalides 2003, Joseph 1997, Salih 1978). Between the constitution's codified consciousness and the Cypriot ones, there was a deep communicative mismatch. It appeared before the Cypriot representatives, as the outcome of the reflective cooperation of external systems of reason, which, after being temporarily hijacked by the two closures' dialectic, witnessed their inherent inability to construct widely inclusive parameters of survival. Mainly the Greek, and to a much lesser degree the Turkish system of political rationalism, by widening the parameters of survival, have instituted a way of political regulation that will resituate Cyprus consciousness within the western table of functional rationalism. Consequently, the constitution, as the assimilation of all worldviews within an extended western table of sustainability, did appear before closures as a disruptive event. So, they had to invent the means for accommodating it. On the one hand, this constitutional regulative attempt has as a point of departure the existing division, and on the other hand, it establishes the structures that could rerail closure's destructive dialectic. It also establishes mechanisms, by means of inserting the "foreign consciousness" in highly important structures of the newly established state, that were aiming at absorbing the distortions in communication between the two worlds. Since the proposed constitution was based on the prospect of the co-

\footnotetext{
${ }^{12}$ The Greek Cypriot consciousness gradually causes a rupture within the British colonial policy. Thereafter, it follows a deep British reflection on the Cyprus problem that leads to the conception of a corrective model based on an evolutionary and creative synthesis of the two closures. The Radcliffe constitution was the maturation of this British attempt to institute beyond the limits of the two ethnic closures. See Reddaway 1986, Kelling 1990, Hatzivassiliou 1997.
} 
evolution of the two consciousnesses, it was in itself a call for an evolutionary leap of Cyprus consciousness so it could synchronize itself with it. To put it differently, a qualitative transformation of the existing Cypriot consciousness was the condition for its existence and application. The event of its final adoption by the Cypriots was in itself a radical act, mainly because of Archibishop Makarios. A communicative link was made possible, but because the ground on which this link was made was very weak, its existential roots have been later lost. As a result of this, the cooperative management of the Cypriot state ceased to exist.

After 1963, the two closed spheres of reason attempted to retreat ideologically to the pre-constitutional order of things. They pursued their own process of reification on the Cypriot land by enacting a new phase of their dialectic, that of territorial division. There was a clear mismatch between the actual stage of development of the two consciousness and the regulations in the constitution. Regardless, they concurrently entered a stage whereby a shadowy self-corrective mechanism had been slowly set in motion, arising out of a splitting within the two consciousnesses themselves. In their inside a multilayered critical movement was created that elaborates in the silence of historical margin a more functional form of rationality. In the Greek Cypriot world the ghost of enosis returned for a while as the consciousness needed time to regain an authentic relation with historical process on the basis of its own rhythmconstitution. Yet, within the new political environment that was established by the consolidation of the Cypriot State which was irreducible to closures' dialectic, it was confronted by a more developed type of consciousness. Since the structural conditions of the newly established state were governed by a different spirit which initially was not originated in Cyprus, it led Cypriot reason to a different path. The ethnic ideology had a weak modern institutional background due to the structures that were set up, firstly by the British, and then, by the development of the State itself. Nevertheless, the extreme ideology of fanaticism was structured, disciplined, organized and diffused by Grivas, the EOKA A and B leader, whose inherently destructive personal ideology tried to abolish the State. In other words, this ideology of fanaticism, struggles to make a regressive leap to the past in order to implement its own mode of consciousness which was not conditioned by the constitution of 1960. At the same time, nomadic rationalism objectifies the ideology of fanaticism by distancing itself from it. In doing so, it becomes the new victim itself of a differently adjusted ontological expression of a destructively compulsive ideology that has been established on the Cypriot land since 1955, when Grivas equipped ideological closure with polemical means. In truth this split appeared from the beginning of Grivas' activities which were denounced by many Cypriots, who witnessed that as soon as the existential human condition disassociates itself from the oppressive closure, it is subjected to the practice of execution (Alastos 1960). ${ }^{13}$

Through the realization of the aporetic dialectic of the Greek Cypriot strict closure, there is a progressive shift from the compulsive return to the ontological arrest of the motivational drive for evolutionary development, namely enosis, to

\footnotetext{
${ }^{13}$ In fact Grivas' fanaticism has been very early identified as a threatening force for the survival of the Greek Cypriots. And yet, the dispersal of the destabilizing group of fanatics managed at the end, since it was not eliminated, to cause a tragic disorder.
} 
independence. This represents the gradual maturation of historical awareness on behalf of the Greek Cypriot consciousness of the need to follow its own self-made authentic dialectic for progressive evolution and to achieve the necessary existential link with the constitution. This struggle within the Greek Cypriot world between Grivas' pure closure and Makarios' weak nomadic rationalism was contaminated by the cold war's understanding of the movement of liberal rationalism. The so called "Cyprus communist threat" makes possible the identification of the Greek Junta with Cypriot closure and the backing of both on behalf of US political thinking. The latter in fact becomes increasingly hostile to the actual movement of liberal thought in Cyprus. Thus, there is an ontological blocking enforced by all parts concerned, aiming at damaging the movement of nomadic rationalism. Makarios' weak rationalism could only differentiate itself from the ideology of strict closure. It could not establish any communicative links with Turkish Cypriot consciousness and the Western world. ${ }^{14}$ On the contrary, Makarios, by establishing mechanical links with the Soviet world, gradually distanced nomadic rationalism from the western field of functionality (Polyviou 1980: 4-45, Ker-Lindsay 2004: 125-127, Stergiou 2007). But whereas the western field of rationality was functional enough to permit a viable Cypriot model of reason to unfold constructively, the Soviet world was focused on damaging the parameters of survival of the western world. It was only by the mediation of a synchronization with the western world that the Cypriot consciousness could follow a path of progressive development aiming at the invention of the parameters of its own survival.

The Turkish invasion of 1974 was made possible because of the distorted play of reason which created a communicative gap between nomadic rationalism and the western world. The US policy, ignoring the conditions of the polyrhythmic and autochthonous movement of liberal thought that inscribes itself in divergent ideological shields, conceived the emergence of strict closure through the coup d'état as a strategic ally (Hitchens 1984, Markides 2001: 76-78, Kassimeris 2008: 91-114). The British government clearly understood the qualitative difference between nomadic rationalism and strict closure, as well as the Turkish political reason's inability to act as a binding liberal force among Cypriots. In any event, its call for a joined corrective intervention both against the coupists and the Turkish invaders later was refused by the USA (O' Malley and Craig 1999: 176-186, Polyviou 1980: 199-200). ${ }^{15}$ Turkey, identified itself absolutely with the Turkish Cypriot closure, and indifferent to the drama the Greek Cypriots were going through, was left alone to materialize the ideal of partition, that is, the armed freezing of history. However, throughout this distorted play of reasons on a table of strategic miscalculations nomadic rationalism survives. As a result of this, the

\footnotetext{
${ }^{14}$ For Makarios' weak nomadic rationalism, see Mayes 1960: 33, Reddaway 1986: 116, Hatzivassiliou 1997: 61.

${ }^{15}$ The conceptualization of such a plan illustrates the unique British ability to construct functional policies irreducible both to the two ethnic closures and to the singular strategies of the other countries involved. Throughout the course of the Cyprus history, all parties involved (Greece, Turkey, USA) were tested as far as their ability to provide a liberal shield to the Cypriot environment is concerned and they have failed. This British equilibrium was always conceived from both Cypriot sides as representative of the interests of the other. See Markides 2001, Sonyel 1997.
} 
Greek Junta tied with Greek Cypriot fanaticism collapses. More powerful and autochthonous existential processes that have been proved to be more viable than the temporary ontological arrest of the liberal movement, rendered the strategic sustainability of the cold war unworkable before it exhausted all its possibilities and collapsed.

\section{Cypriot Consciousness Divides Itself}

After the armed Turkish invasion of 1974, the two ethnic worlds established themselves on a divided time and space. At the same time, nomadic rationalisms were developing their own dialectic of creative divergence and accumulation, a process that could not be recognized by official strategic calculations. The extreme ideology of Grivas' fanaticism had been expelled from the Cypriot land and the Turkish Cypriots found their consciousness frozen into the materialization of the ideal of taksim. By understanding the post invasion period as the solution of the problem itself, the Turkish Cypriots attempted to block the progressive movement of the Cypriot spirit (Oberling 1982, Volkan 1998: 277-284). That said, the two official ideologies, being structured on limited models of parameters of survival, were following a dialectic of aporia. For example, both the ideology behind the S300 missile deployment strategy and the Turkish Cypriot opposition to the Cyprus Republic accession into the EU illustrates a line of thought that runs out of functional applicability (Friss 2002, Stivachtis 2002: 34-53). ${ }^{16}$ An artificial pressure backed by polemical means was irrelevant to an autonomous dialectic of co-evolution at a point in time where a will for solution meant a genuine resolve for the enlargement of the parameters of survival. On the other hand, the Turkish Cypriot political thinking overlooked the process of entering the EU as one of gradual mutation of parameters of survival whereby the Cypriot mental world as a whole would be subjected to a process of deconstruction, over whose rules, despite its own intentions and declarations, it has no control at all.

Within this post-invasion environment, an official ideology is constructed through the institutionalized mechanisms of control and the dissemination of knowledge. Its main feature is that it is associated with an ethical material that does not allow the crossing of the boundaries and the construction of wider parameters of survival that are applicable both to the Cypriot environment and its outside. All the same, closures built their dialectic on a general structure of a silent dialectic with a greater life span. Not only do they not control this dialectic, but in itself gradually disturbs and threatens them with dismantling. The great miscalculation of closures is that they ignore the silent process of mutation of mental and moral systems. Their recurring historical refusal to accept the concept of progressive cognitive and ethical mutability that occurs within historical process makes them representative of an early stage of development of consciousness.

\footnotetext{
${ }^{16}$ In these two accounts, the Cypriot closures are considered as the only systems that are charged with the responsibility of managing the movement of history. Thus they silence the dialectic of the Cypriot nomadic rationalisms that defy the official strategic, economic and political calculations on which the prevailing discussion of the Cyprus problem is still based.
} 
Nomadic rationalisms codify the ontological byproducts of this ethical mutability which is at work. In so doing, they widen the scope of the parameters of survival through the conceptualization of inclusive mechanisms aiming at the well-being of all Cypriots. Against the social, economic, ideological and cultural materialization of the two Cypriot closures, there is a silent mental shift and displacement. It provides in itself the ground for a movement of critique emanating of witnessing the failure of the closures. The latter manifests itself through a chain of uncontrolled events that accompany a crisis. In periods of crisis, where the depth of the field of rational functionalism is tested, there is an unmasking of the unworkability of the whole ideological, institutional and practical edifice. Nomadic rationalisms' synchronous process of reflection always aims to respond to the failures of the two worlds. Through the mediation of an enlarged consciousness governed by a will to become an actual reality, they develop a reconstructed Cypriot reality which is nurtured in a representational network.

Nomadic rationalism is what prevents the closed worlds from uninterruptedly actualizing themselves. They represent the ontological figuration of the collective conscience of Cypriots as the product of the condensed wisdom emerging out of the reactivation in memory of the historical failures of the past and the aporias of the present. This mutation in process, struggles to redefine the boundaries of survival not on the basis of inactive ideological artifacts but on the basis of a shared universal human condition. Because nomadic rationalism moves beyond the structure of closures mental and existential development, it consists of an internal force of resistance. Because of this, there is an evolutionary gap between themselves and the closed worlds within which they advance.

\section{The Antagonism between Closures and Nomadic Rationalisms}

The boundaries of the mental and moral space of the Cypriot closures that for almost century have conditioned the movement of Cypriot history have been transgressed. As a Consequence, the reality they sustain loses institutional, practical and ontological ground. Therefore, Cyprus history could rather be examined from the perspective of nomadic rationalisms which consist of a systemic divergence that will be reserved by means of becoming actual reality. This modified form of Cypriot consciousness by inserting itself into the Cypriot world will cause a series of other corresponding changes. The gradual process of reification of nomadic rationalism will result in the gradual displacement of the axioms of the closed worlds. The very existence of the closed worlds, and the whole apparatus that this involves, boils down to the Cyprus problem. The process of reification of nomadic rationalisms and the creation of new institutions and novel places inspired by them, heralds the beginning of a process of liberalization. To expect the closed worlds to solve the problem is to ask them to dissolve themselves; it is a logical paradox because the mental and moral systems of the closures are mutually exclusive (Fisher 2001: 322). ${ }^{17}$

\footnotetext{
${ }^{17}$ Examining the history of the third-party interventions, summarizes the incompatibility of the two
} 
It is only through the grounding of the dialectic of reification of nomadic rationalisms that a strategy for solution-liberalization could possibly open up. Firstly, nomadic rationalisms need to institutionalize themselves within the world they belong to, and thereafter, manage to subject the structuring of the spatiotemporal Cypriot field upon their own dialectic. In their present stage their creative impulse is very low, and as such, they are confined within the field of reflection and objectification that the two closures have created for them. The outcome of this antagonism within the two spheres of the Cypriot world will bring into being the shaping of a new form of reason that, in its turn, will seek to liberalize them through the new dynamic that its reification will create. Since this dynamic is based on the condition of the consolidation of the nomadic rationalisms, its evolutionary formation will not be reducible to them. The process of objectification of nomadic rationalisms will result in a progressive leap of consciousness whereby both worlds will acquire an inherent will for widening their own horizons and enhance their workability.

The liberalization of the two worlds in itself, and also the new state of things that will result, should initiate a process of modernization of the Cypriot worldsphere as a whole. During this more advanced stage of convergence and readjustment of consciousnesses, nomadic rationalisms will start intercrossing and merging. In doing so, they will, on the one hand, condition the movement from one world to the other without a communicative defect, and on the other hand, they will eliminate the ground on which violence is accumulating. From this point of view, solution is coupled with progressive liberalization. Therefore, it is not something that will erupt before the Cypriots, aiming through technical means to bridge the existing gap between their consciousnesses. Rather, solution is equivalent to the ascending development of nomadic rationalisms themselves at a point in time and place. By virtue of this, the liberalization of Cyprus as a whole will be identical to their autonomous and natural will for liberalization. Nomadic rationalisms will inscribe themselves within the process of solution, establishing thus an evolutionary affinity with it.

\section{Deconstructing Cyprocentrism}

What is invoked here through the use of the term of nomadic rationalism is an accommodating form of consciousness that cannot be confined within an ethnic spatial and temporal field. In our age nothing is allowed to be closed within itself and thereafter to develop a sharp sense of differentiation in relation to what it perceives as external. Furthermore, ethnicity can neither serve as the base for effective communication, nor can it explain the worldwide model on which modern communication is practiced. The lack of environmental adjustment of the Cypriot thought explains the fact that all population-related parameters of survival in Cyprus have failed. Cyprocentrism was the necessary, but now an ontologically

regimes of truth as follows: "the parties are caught in self-defeating processes of antagonism, including blaming the other side, attributing negative qualities to them, and polarizing one's own side against them." 
exhausted, product of the movement of thought in an age where historicity, due to the existing stage of development of technology and the interlinked understanding of time and space, was subjected to a different pace (Salih 1978: 26-30, Doob 1986: 383-38, Attalides 2003: 57-79, Mavratsas 1997). ${ }^{18}$ Although Cyprocentrism, despite its own claims, represents a struggle towards communal confined liberalization, it does not have the essential means at its disposal to do so. This is because it conceptualizes itself through a static spatiotemporal environment as it differs from other systems of reason. Furthermore, it is in itself a contaminated ideology since one aspect of cyprocentric attitude, as it has been manifested in Cypriot history, is not the product of an active historical consciousness. More specifically, as far as the way it understands itself in relation to Greece, it hides within itself a pragmatic communicational falling between Greek and Greek Cypriot political thought. Until 1967, islands of Greek thought were trying desperately to communicate with and to reorient the disastrous dialectic of the Greek Cypriot political activity (Georgallides 1979: 106-112, Hatzivassiliou 1997: 122). Rather, what this analysis refers to is a transnational form of reason, a planetary zone of functionality that cannot be claimed because it is a byproduct of thought that has no spatiotemporal limits, as is the case of Cyprocentrism. The two Cypriot nomadic rationalisms indeed share many of their axioms. However, this is not because of a common Cypriot identity that needs to be recovered from the past and be illustrated in terms of its divergence from other identities. Nomadic rationalisms do communicate effectively because, although for a long time they were developing in complete isolation from one another, they do share a set of universalizable islands of rationality that are being structured by a common human condition. These parcels of rationality are the ontological answers to a human state of mind that desperately needs to find a refuge in the sphere of Cypriot ontological life. Progressively, the universal human condition lived in Cyprus from its various origins inserts itself into ontology that takes the form of meaning. This workable and existentially condensed form of meaning which circulates from one world to the other is irreducible to the official views of the world imposed by the two closures.

Cypriot closures, by colonizing existential conditions and by confining them within strict ethnic boundaries, become employable only within their own narrow horizons. It is from this perspective that their inherent tendency to silence and eliminate the other could be understood (Thompson 2000: 251-252, Loizos 1998: 646, Packard 2008). Unlike closures, nomadic rationalisms bypass their hegemony by giving ontological expression to a universal human condition experienced also by all Cypriots. Furthermore, closures cannot communicate their system of thought to different worldspheres. On the other hand, nomadic rationalisms communicate effectively with liberal flavours of European, British, American, Greek and Turkish thought. Nomadic rationalism is Cypriot because above all it

\footnotetext{
${ }^{18}$ The common thread of such an argument goes as follows: to emphasize the common Cypriot interests and identity as they vary from the Greek and Turkish ones. Such accounts ignore the restraining influence exerted throughout the Cyprus history on strict closures by both the Greek and Turkish thought. Secondly, the mere invocation of the common interests and of shared identity does not necessarily mean that there is a guaranteed form of functional rationalism.
} 
converges with worldwide dispersed islands of functionalism which as such raise claims of universality. Nomadic rationalism aims to replace the form of consciousness that was employed within territorial boundaries, that can be named, and which moreover, as a condition for its existence, needs to liberate itself from the influence of other systems of thought. The historical inability of this mode of consciousness to communicate with international systems of thought is one aspect of the Cyprus problem itself. So, here it is argued that what can unite the Cypriots can unite the Greeks, the Turks and the world as a whole, namely, a viable and well tested form of reason that responds to, and ontologically objectifies a universal human condition. Similarly, what can divide Cypriots is what can divide Greeks, Turks and the world as a whole, namely a mode of reason, lacking in functionality, and thus in ethics, and as a result of this, is neither applicable nor viable. When Cypriot nomadic rationalism throughout modern history repels against a type of Greek reason and when the Turkish Cypriot nomadic rationalism repels against a type of Turkish reason, they do so for the same reason they establish an alliance with different origins of Greek and Turkish reason respectively. ${ }^{19}$ They converge with the liberal elements and diverge from the distorted ones of each systemic world respectively. In the case of closures, we have a reversed setting: they demonize Greek and Turkish liberal thought and they seek alliance with bearers of distorted ideologies that are ready to adopt their worldview.

\section{Nomadic Rationalisms and Progressive Ontological Figurations}

Political parties, as official bearers of an articulated meaning, converge and diverge from nomadic rationalisms variously. Nevertheless, nomadic rationalisms, like closures, are irreducible to them. Political parties can neither claim nor be immune to both. It is by understanding the ground of both closures and nomadic rationalisms as being pre-ontological that we can conceptualize the dialectic of both the antagonistic forces in Cypriot history as far as coalitions, displacements, convergences and divergences are concerned. Generally, they consist of the ground where the constant structuring and restructuring of ontological meaning takes place, a process far more dynamic than that of the hegemonic political contest. The Cypriot functional rationalism is multilayered. It precedes and transcends its official ontological manifestation in such a way that, while it grants ontologically the official political discourse, it is not exhausted by it. $^{20}$ On the

\footnotetext{
${ }^{19}$ The Greek Cypriot closure formed an alliance with the Greek conservative forces while the Greek governments where trying to prevent its disastrous dialectic. The Turkish Cypriot closure allied itself with the movement of panturkism. See Kitromilides 1979: 166-167, Georghallides 1985, Crawshaw 1978: 45, McHenry 1987: 293, Holland 1998: 67.

${ }^{20}$ The more closures actualize their mechanisms of response to an external challenge, the more meaning they release to their outside environment due to the illustration of their disfunctionality. The reflective processes that the discussions over the Annan Plan have actualized, fused the Cypriot environment with unusual historical energy that caused a mental shift in both the Cypriot worlds. The whole discussion over the Annan plan gathered together the forces of progressive liberalism against the forces of strict closure. In the Turkish Cypriot community, the corrective influences, due
} 
contrary, political parties very oftenly neutralize and slow the pace of its development. AKEL, for example, could be construed as the historical systemic force that disrupted the mechanical unfolding of the Cypriot closures within the Cypriot field. Its static and dogmatic ideological alliance with the international communist ideology was initiated by an active and authentic will to widen the parameters of survival, mainly within the Greek Cypriot community. Addressing fundamental existential conditions that the instrumentality of the Church establishment ignored, it grounded the dialectic of liberal thought in Cyprus (Mayes 1960: 66-81, Crawshaw 1978: 34). Ethical responsiveness, social cooperation and widely circulated trust were additionally strengthened as a byproduct of AKEL's structural deployment in the Cypriot environment. ${ }^{21}$ On the other hand, because of the recurring silencing of an autochthonous dialectic of development by the typified alignment with the international communist world, a symptom of the all-encompassing energy of closure within the Cypriot field, AKEL contributed to the dangerous distancing of nomadic rationalism from the sphere of western liberal reason.

Nomadic liberals, in the new rhythmic pace of Cypriot consciousness, arise out of the multi-centered actual field of practical life. That is to say, they are active within in a network of mental times and spaces where programmed ideologies are inactive, suspended and not applicable. In these active islands of departure from the hegemonic ideologies where modes of functionality have been augmented, the movement of nomadic liberalism creates an affirmative block of resistance against the power of Cypriot closures. The latter are oriented towards its own elimination. ${ }^{22}$ Accordingly, an existential anxiety is disseminated within nomadic rationalisms. The unheard voice of the silent revolution of the Cypriots throughout history is out of synchronization. ${ }^{23}$ They live in a worldly reality which has no relation with the

to an intense period of reflection on the applicability of hegemonic values and the illustration of their unworkability, were powerfully expressed through their "quiet revolution" in 2003. See Michael 2007: 598-599.

${ }^{21}$ It is here that we can trace the binding relationship of AKEL with social liberalism. Fukuyama (1995) has shown that the ethical values of social cooperation, widespread trust and social solidarity beyond one's kinship, on which liberal democracy and the market system are truly based, were structured on pre-existing communities. AKEL has widened the abilities of social cooperation on the basis of existential needs that bypassed the dominance of the village-centred ethics. See Loizos (2004). This enlarged ability for communal cooperation and a certain grade of widespread trust grounds the conditions for the existence of "Cyprus economic miracle" after the disastrous Turkish invasion. On this see Christodoulou (1992).

${ }^{22}$ See Constantinou and Papadakis (2002); Constantinou (2007). The shared existential condition of the two Cypriot nomadic rationalisms has been demonized by the hegemonic value systems which apply in an identical way the same exclusive mental and ethical axiom. Namely, the arrest of the ethical and rational employability within strictly defined spatiotemporal boundaries. This betrays a systemic problem of the Cypriot environment: in insisting on imprisoning ethical responsiveness within an ethnically populated area, it tries to silence those who are spirited by a more inclusive moral system that is applicable to a larger population.

${ }^{23}$ Navaro -Yashin (2003) encapsulates this existential alienation with the phrase "life is dead here." However, it is under the spectre of absence, frozen life, helplessness, powerlessness and of a lifeless spatiotemporal environment that the greatest mobility of nomadic rationalism is produced. That is, by the greatest immobility of a sealed environment under armed closure. The motor of nomadic rationalism is to get the greatest power out of the greatest sense of powerlessness. It is this 
imaginary Cyprus they nourish and are animated by. From the point of view of a philosophy of the future of Cypriot consciousness, this very fact grounds the beginning of the dialectic of reification of nomadic rationalisms and their will to become a renovated reality. Since nomadic rationalisms exist, the process of their reification, albeit a troublesome one, has been grounded. It is indeed through this antagonism, which because of the contamination of this autochthonous dialectic with distorted and frozen ideological artifacts has been postponed many times throughout history, that Cypriots, by means of consolidating institutionally the products of their silent revolution, will displace the closures that brought unbearable suffering to the people of Cyprus.

\section{Solution: Liberalization as a Rational Equilibrium}

Nomadic rationalism could serve as the force that could speed up the insertion of the Cypriot lifeworld into a harmonization process with a wider field of global liberalizing mechanisms. It could also work as the receptive communicational bridge with external systems of functional rationalism. Nomadic rationalism could firstly set the parameters of survival of all Cypriots on the basis of a developed sense of justice, under the energy of which, novel places, inclusive institutions, architectural interventions, practices and discourses would be generated. Secondly, it could establish existential links of communication with both liberal forces in Greece and Turkey. In doing so, it would disassociate functional rationalism from the rigid category of the "nation - state." Thirdly, it could inscribe itself within the European dialectic which by virtue of its deployment has already disclosed the enclosure of human experience within spatiotemporal limits of employability as a structural defect. The accession of Cyprus to the EU has weakened the closures' applicability, despite their initial intention to use the EU as a new field for their own strengthening. ${ }^{24}$ The more closures approach the EU through internal adaptation procedures the less effective they become. This is because one of the conditions of their existence is that they developed in isolation from other rational systems. On the other hand, nomadic rationalisms' unnoticed dialectic grew

\footnotetext{
silent and unheard subjective sensibility that builds the ground for the strongest edifices of functional rationalism in Cyprus and constitutes the motor of the silent Cypriot revolution: namely, the demand of the divergent Cypriot existential condition to accumulate, preserve and reify itself both ontologically and institutionally, and by doing this, to defreeze the structure of the unthought by means of which the Cypriot closures keep themselves outside the field of novelty.

${ }^{24}$ For the initial strategy of the Greek Cypriot closure to enter the EU in order to enforce its own stand of deployment, see Mavratsas (1998). Concerning the view of the Turkish Cypriot closure of the accession process of the Cyprus Republic to the EU, see Brewin (2000). Instead of imposing its own strategic plan, which included among other things the unification with Turkey, the Turkish Cypriot closure was disrupted by the elective affinity of the Turkish Cypriot nomadic rationalism with the systemic rational functionalism of the EU. This historical paradigm illustrates clearly the false consciousness which orients the strict closures: while they aim at empowering themselves through the mechanical use of a wider field of functionality, they end up facing the impasses of their disfunctionality. The strict closures do not possess a progressive dialectic, and any analysis following their own declared aims, ends up witnessing the emergence of a new reality that is not covered by the horizons of their expectation.
} 
enormously due to the witnessing of closures' failure to survive in a field of a more demanding conceptual framework. For that reason, nomadic rationalisms' alignment with a process of enlargement of the parameters of survival creates the conditions for establishing mechanisms that create mental attitudes and social places that include all Cypriots.

Cypriot nomadic rationalisms, after attaining the necessary horizon of functional development which can firmly attract and bind them to the existential grounding of liberal thinking beyond its ontological articulations, could aim for Turkey's accession to the EU. Turkey's process of adjustment with the European mode of functional rationalism could serve as the condition for the merger of nomadic rationalisms involved in the Cyprus issue. The event of such a merger could replace the existing ethical imperative with one that autonomously politically thinks and acts only on the basis of whether its disposition sustains the survival of a whole which is always under enlargement. This merger of nomadic rationalisms could enable Turkish political thinking to include into its own conceptual horizon the survival of all Cypriots and not only that of Turkish Cypriots, as was the case with the ideological structure that grounded the armed invasion of 1974. This very framing of the existential condition within ethnic boundaries resulted in a recurring backing of the Turkish Cypriot closures' dialectic for restructuring the Cypriot space on the basis of a regressive ethical horizon that in real terms advocates that the mutation of existential condition in Cyprus is historically impossible and unthinkable.

The historical destination of the dialectic of the active, hence irreducible to ontological constructions, Turkish functional rationalism is the accession to the EU. This fact in itself means that Turkey could restructure its mental and ethical boundaries that are applied to Cyprus so they might accommodate the unified Cypriot nomadic rationalisms' resolve for reorganizing the ethical imperative on the basis of the survivability of all Cypriots. After all, the identification of progressive Turkish political thinking with Turkish Cypriot closure throughout modern history was instrumental, and it was bound to break apart because there was a real liberal discrepancy between the two systems of interpretation. ${ }^{25}$ The recent communicative bridge established in between 2003 to 2010 the liberal forces in Turkey and in Turkish Cypriot nomadic rationalism that resulted in the weakening of the Turkish Cypriot closure that was spirited by Denktaş, illustrates the prospect of building upon a peripheral movement of functional liberalism whose pre-ontological ground is not identified with its historically manifested established content (Bahcheli 2009, Hatay and Bryant 2008).

\footnotetext{
${ }^{25}$ The Turkish Cypriot consciousness delayed in terms of the modernization process that was taking place in Turkey guided by the spirit of Kemalism. See Oberling 1982: 52-56, McHenry 1987: 164167. The way Turkish Cypriot consciousness subjected Kemalism to an irredentist policy was similar to the way the Greek Cypriot consciousness subjected the Greek political consciousness to the tradition of the Greek Irredentism.
} 


\section{Conclusion}

Solution as liberalization is a process, and as such, it can never be frozen into a constitutional arrangement. The latter is a necessary starting point but therein lies the danger of freezing in time and space an on-going movement of the Cypriot spirit to develop itself, and through this, to subject the actual world to a process of recreation in accordance with this corresponding grade of development that maybe acquired in time. Certainly, a constitutional settlement would reflect the grade of development that the two nomadic rationalisms can reach at a certain point in time. Nonetheless, this constitutional arrangement needs to be internally fused with some islands of flexibility and rearrangement. This is because its actual reality will be bypassed by the next stage of development of Cypriot consciousness, which, although it cannot predict, it can develop a will to infuse it within the constitutional arrangement. The latter should thus be construed as the beginning of an evolutionary process of the active Cypriot consciousness and not as the point of its perfectibility.

\section{References}

Adams TW (1971) AKEL: The Communist Party of Cyprus. California: Hoover Press.

Attalides M (2003) Cyprus: Nationalism and International Politics. Mannheim: Bibliopolis. Alastos D (1960) Cyprus Guerilla. London: Heinemann.

Arendt H (1978) The Life of the Mind. Chicago: The University of Chicago Press.

Bahcheli T (2009) "The Rise of AKP party and Ankara's Changing Role: Paving the Way for the Yes." In Reunifying Cyprus: The Annan Plan and Beyond, H Faustman, A Varnava (eds). London: I.B. Tauris.

Banfield E (1958) The Moral Basis of a Backward Society. New York: Free Press.

Brewin C (2000) The European Union and Cyprus. Huntingdon: Eothen.

Castoriadis C (1997a) World in Fragments. DA Curtis (ed). Stanford: Stanford University Press.

Castoriadis C (1997b) The Imaginary Institution of Society. K Blamey (transl). Cambridge: Polity Press.

Christodoulou D (1992) Inside the Cyprus Miracle: The Labours of an Embattled MiniEconomy. Minnesota: University of Minnesota Press.

Crawshaw N (1978) The Cyprus Revolt: an Account of the Struggle for Union with Greece. London: George Allen and Unwin.

Constantinou C, Papadakis Y (2001) The Cypriot State(s) in Situ. In The European Union and the Cyprus Conflict, Diez (ed). Manchester: Manchester University Press.

Constantinou C (2007) Aporias of Identity: Bicommunalism, Hybridity and the Cyprus Problem. Cooperation and Conflict 42(2): 247-270.

Diez T (2002) The European Union and the Cyprus Conflict. Manchester: Manchester University Press.

Doob L (1986) Cypriot Patriotism and Nationalism. Journal of Conflict Resolution 30(2): 383-396.

Fisher R (2001) Cyprus: The Failure of Mediation and the Escalation of an Identity-Based Conflict to an Adversarial Impasse. Journal of Peace Research 38(3): 307-326.

Foucault M (2001) Fearless Speech. Los Angeles: Semeiotexte.

Friss A (2002) The European Union's Eastern Enlargement and Cyprus. In The European 
Union and the Cyprus Conflict, T Diez (ed). Manchester: Manchester University Press. Fukuyama F (1993) The End of History and the Last Man. New York.

Fukuyama F (1995) Trust: The Social Virtues and the Creation of Prosperity. London: Hamish Hamilton.

Georghallides GS (1979) A Political and Administrative History of Cyprus, 1918-1926. Nicosia: Cyprus Research Centre.

Georghallides GS (1985) Cyprus and the Governorship of Sir Ronald Storrs: the Causes of the 1931 Crisis. Nicosia: Cyprus Research Centre.

Hatay M, Bryant R (2008) The Jasmine Scent of Nicosia: Of Returns, Revolutions, and the Longing for Forbidden Pasts. Journal of Modern Greek Studies 26: 423-449.

Hatzivassiliou E (1997) Britain and the International Status of Cyprus, 1955-1959 Minnesota: University of Minnesota.

Hegel GWF (1956) The Philosophy of History. J Sibree (transl). New York: Dover Publications.

Hitchens C (1984) Hostage to History. Cyprus from the Ottomans to Kissinger. New York: The Noonday Press.

Holland R (1998) Britain and the Revolt in Cyprus 1954-1959. Oxford: Clarendon Press.

Joseph J (1997) Cyprus: Ethnic Conflict and International Politics. London: Macmillan Press.

Kassimeris C (2008) The Inconsistency of United States Foreign Policy in the Aftermath of the Cyprus Invasion: The Turkish Arms Embargo and its Termination. Journal of Modern Greek Studies 26: 91-114.

Kelling HG (1990) Countdown to Rebellion. New York: Greenwood Press.

Ker-Lindsay J (2004) Britain and the Cyprus Crisis, 1963-1964. Manheim and Möhnesse: Bibliopolis.

Kitromilides P (1979) The Dialectic of Intolerance: Ideological Dimensions of Ethnic Conflict. In Small States in the Modern World, P Worsley, P Kitromilides (eds) 143184. Nicosia: The New Cyprus Association.

Kojeve A (1980) Introduction to the Reading of Hegel. J Nichols (transl). Ithaca: Cornell University Press.

Kyrris C (1996) History of Cyprus. Nicosia: Lampousa Publications.

Lanitis NC (1963) Our Destiny. Nicosia: Mouflon.

Lefebvre H (1991) The Production of Space. D Nicholson (transl). Oxford: Blackwell.

Lefebvre H (2003) The Urban Revolution. R Bononno (transl). Minneapolis: University of Minnesota Press.

Lefebvre H (2004) Rhythmanalysis: Space, Time and Everyday Life, S Elden and G Moore (transl). London: Continuum.

Loizos P (1974) The Progress of Greek Nationalism in Cyprus, 1878-1970. In Choice and Change: Essays in Honour of Lucy Mair, J Davis (ed.). London: The Athlone Press.

Loizos P (1998) Intercommunal Killing in Cyprus. Man (N.S.), 23(4): 639-653.

Loizos P (2004) The Greek Gift: Politics in a Cypriot Village. Manheim and Möhnesse: Bibliopolis.

Luke H (1957) Cyprus: A Portrait and Appreciation. London: George G. Harrap \& Co.

Markides D (2001) Cyprus 1957-1963: From Colonial Conflict to Constitutional Crisis. Minneapolis: University of Minnesota Press.

Mavratsas C (1997) Greek-Cypriot Nationalism and Cypriotism. Ethnic and Racial Studies 20(4): 717-737.

Mavratsas C (1998) Greek-Cypriot Political Culture and the Prospect of European Membership: a Worst- case Scenario. Cyprus Review 10(1): 67-74.

Mayes S (1960) Cyprus and Makarios. London: Putnam.

McHenry J (1987) The Uneasy Partnership on Cyprus, 1919-1939. New York: Garland 
Publishing, Inc.

Michael M (2007) The Cyprus Peace Talks: A Critical Appraisal. Journal of Peace Research 44(5): 587-604.

Moran M (1997) Rauf Denktash at the United Nations. Huntingdon: The Eothen Press.

Navaro-Yashin Y (2003) Life is Dead Here. Anthropological Theory 1(3): 107-125.

Oberling P (1982) The Road to Bellapais: The Turkish Cypriot Exodus to Northern Cyprus. New York: Columbia University Press.

O' Malley B, Craig I (1998) The Cyprus Conspiracy. London: I.B. Tauris Publishers.

Packard M (2008) Getting it Wrong. Milton Keynes: Authorhouse.

Polyviou P (1980) Cyprus: Conflict and Negotiation, 1960-1980. London: Duckworth.

Rawls J (1971) A Theory of Justice. Harvard: Harvard University Press.

Reddaway J (1986) Burdened with Cyprus. London: Weidenfeld and Nicolson.

Salih I (1978) Cyprus: The Impact of Diverse Nationalism on a State. Alabama: the University of Alabama Press.

Soneyl S (1997) Cyprus: The Destruction of a Republic. Huntingdon: The Eothen Press.

Stergiou A (2007) Soviet Policy toward Cyprus. Cyprus Review 19(2): 83-106.

Stivachtis G (2002) Greece and the Eastern Mediterranean Region. In The European Union and the Cyprus Conflict, T Diez (ed), 34-53. Manchester: Manchester University Press.

Storrs R (1945) Orientations. London: Nicholson and Watson.

Tarrow S (1998) Power in Movement. Cambridge: Cambridge University Press.

Thompson P (1999) The Evolutionary Ethics: Its origins and Contemporary Face. Zygon 34(3): 473-484.

Thompson P (2002) The Evolutionary Biology of Evil. Monist 85(2): 239-259.

Tocqueville A (1969) Democracy in America, G Lawrence (transl). New York: Harper and Row Publishers.

Trilling L (1971) Sincerity and Authenticity. Harvard: Harvard University Press.

Volkan V (1998) Turks and Greeks of Cyprus. In Cyprus and its People, V Kalotychos (ed), 277-284. Colorado: Westview Books. 